\title{
Characteristics of Activated Carbons Prepared from Apricot Kernel Shells by Mechanical, Chemical and Thermal Activations
}

\author{
Marat Isakovich Satayev ${ }^{1}$, Ravshanbek Sultanbekovich Alibekov ${ }^{1}$, Lazzat Mutalovna Satayeva ${ }^{1}$, Omirbek \\ Pernebaiuly Baiysbay ${ }^{1} \&$ Botagoz Zhaksylykovna Mutaliyeva ${ }^{1}$ \\ ${ }^{1}$ M. Auezov South Kazakhstan State University, Kazakhstan
}

Correspondence: Ravshanbek Sultanbekovich Alibekov, M. Auezov South Kazakhstan State University, 160012, Shymkent city, Kazakhstan. E-mail: ralibekov@hotmail.com

Received: December 3, 2014

Accepted: December 13, 2014 Online Published: April 25, 2015

doi:10.5539/mas.v9n6p104

URL: http://dx.doi.org/10.5539/mas.v9n6p104

\begin{abstract}
The regulating of a structure and a pores volume of activated carbons by mechanical, chemical and thermal activations of agricultural wastes, such as apricot kernel shells were studied. The mechanical activation was provided in the grinding mill, in the aqueous medium. The chemical activation was implemented by treatment with sulfuric, hydrochloric, phosphoric acids at the concentrations of $5 \%-40 \%$ and by zinc chloride at the penetration coefficients of $0.1 \div 0.6$. The thermal activation was effected in carbon dioxide atmosphere at the temperatures of $300 \div 100{ }^{\circ} \mathrm{C}$. It was researched an influence of acid concentration, $\mathrm{ZnCl}_{2}$ coefficient of impregnating, $\mathrm{CO}_{2}$ temperature per volume of micro-, meso- and macropores. Activated carbons have arranged porous structures in the following line: processed by $\mathrm{ZnCl}_{2}$ and $\mathrm{CO}_{2}>$ processed by $\mathrm{ZnCl}_{2}>$ processed by $\mathrm{H}_{2} \mathrm{SO}_{4}>$ processed by $\mathrm{H}_{3} \mathrm{PO}_{4}$. For the samples are treated by $\mathrm{ZnCl}_{2}$ and subsequent $\mathrm{CO}_{2}$, the activation optimal parameters are following: temperature of $\mathrm{CO}_{2}=500{ }^{\circ} \mathrm{C}$; the penetration coefficient $=0.4$.
\end{abstract}

Keywords: adsorption, activation, activated carbon, apricot, pore, wastes

\section{Introduction}

In the current chemical, pharmaceutical and food industries, the adsorption process is widely uses for the technological processes, such as a deep purifying and dewatering, as well as for the improving a quality of raw materials and products. In the production of activated carbon, initial raw materials undergo thermal processes without air. In result volatile compounds remove moisture and particularly resin (Keltsev, 1984). The structure of the obtained coal is a macroporous, and it cannot be used directly as an industrial adsorbent. The task of obtaining a specific microporous structure is solved during the activation process. The activation process is performed by two basic methods: the oxidation by gas or steam, or a mixture thereof (Ahmedna et al., 2004; Tangjuank et al., 2009).

Activated carbons can be prepared from different kinds of natural raw materials. Activated carbons are characterized by a high mechanical strength that produce from coconut shells and other nuts (Branton et al., 2011), from nutshells by chemical activation, by using $\mathrm{NaOH}$, as the activation agent at the $700^{\circ} \mathrm{C}$ (Park et al., 2006). As well as fruit kernels: activated carbon obtained from fruit or olive pits (Tlas et al., 1998), including carbonization of olive fruit or seeds and combined-cycle activation, from almond shells by carbonization in $\mathrm{N}_{2}$ stream with following activation in $\mathrm{CO}_{2}$ stream (Rodrigues-Reinoso et al., 1984); from plum kernels by carbonization and subsequent $\mathrm{CO}_{2}$ activation and direct $\mathrm{CO}_{2}$ activation (Rodriguez-Reinoso et al., 1985); from macadamia nuts by activation at the $900{ }^{\circ} \mathrm{C}$ with a mixture of water steam, air and carbon dioxide (Sato Eiichi, 1986). Further from almond and olive shells by using variety methods: a) carbonization in $\mathrm{N}_{2}$ stream of and the subsequent $\mathrm{CO}_{2}$ activation, b) direct $\mathrm{CO}_{2}$ activation, c) treatment at the dry air stream at the $300{ }^{\circ} \mathrm{C}$ and subsequent $\mathrm{CO}_{2}$ activation (Linares-Solano \& Rodpez-Gonzales, 1984).

In the result of numerous experiments were estimated that a quality of the activated carbon from the nut shells or fruit kernels, commonly relates to the gradual and continuous removal of volatile aromatic substances. The quantity of these in the fruit raw material is $70 \%-78 \%$. In addition significant roles in the target porous structure have sizes of the raw material. It has investigated the adsorption capacity of activated carbon derived from the fruit kernels and nut shells (Golubev et al., 1998), by carbonization in a flow of carbon dioxide at the temperature range $400 \div 750{ }^{\circ} \mathrm{C}$ in a ratio of shell and gas $1: 100 \div 200$, by cooling a carbonate until the $20 \div 50{ }^{\circ} \mathrm{C}$ and recarbonization at 
the $750 \div 900^{\circ} \mathrm{C}$, by the vapor-gas activation and sieving the final product. In the proposed method of the porous structure of carbon adsorbents were formed in the process of carbonization due to the removal of volatiles and the adsorption of carbon dioxide that prevents the cracks formation, blisters and swelling of coal particles after various hydrocarbons, organic radicals, hydrogen and others. During cooling, the formation of primary carbonate completes a porous structure and also the formation of a monolithic skeleton. Carbonation of Manchurian nutshells (Avramenko et al., 1992) in two stages ensures the formation of a dense structure of carbonized material and, consequently, higher mechanical strength of coal and coal provides a high quality, high specific surface area of $1800 \mathrm{~m}^{2} / \mathrm{g}$. The activation of walnut shells (Kutics et al., 1984) at the $500{ }^{\circ} \mathrm{C}$ and $700{ }^{\circ} \mathrm{C}$ does not appreciably change the adsorption properties of initial activated carbon. Such samples have a low adsorption capacity and exhibit selective properties that disappear as the activation. Activation at the $900{ }^{\circ} \mathrm{C}$ increases the adsorption capacity that depends on the time of activation, but activation to the carbonization degrees, more than $60 \%$ in practical. The study of adsorption dynamics of benzene, acetone, $\mathrm{CCl}_{4}$ and suggests a promising application of activated carbon from nutshells for cleaning the air of harmful fumes. On the bases results of the preparing of the active carbons by carbonization of olive kernels (Lopez-Carzon et al., 1984) in $\mathrm{N}_{2}$ atmosphere at the $850^{\circ} \mathrm{C}$ and subsequent activation of the stream of $\mathrm{CO}_{2}$ at the $825^{\circ} \mathrm{C}$. It was concluded that availability the molecular sieve effect in the activated carbons that prepared from olive kernels, on the influence of it on adsorption process in the studied systems. This effect specifies by slit-like pores, whose sizes depend on the activation conditions.

Physical and chemical treatments often use in the production of activated carbon from agriculture waste (Karima Belaroui et al., 2013). Activated carbon received by chemical activation process, has more homogeneity structure in a general, than the structure of coal obtained by thermal activation. In addition, the identity of structure in the process of chemical activation preserves in the granules: their peripheral and internal areas are the same type. Therefore, for precise kinetic measurements should be used only a carbon, activated by chemical methods. The process of chemical activation allows varying the pore structure of activated carbons in a wider range than the combined steam/gas conditions. It was researched the process of obtaining the activated carbon from walnuts, its physical properties and the decolorize ability (Kutics et al., 1984). Pyrolysis temperature and activation time with $\mathrm{ZnCl}_{2}$ had influence on the phenol and methylene blue adsorption capacities of especially for the activated carbons produced from hazelnut and walnut shells (Aygün et al., 2003). For the thermal activation or pyrolysis, the significant values are temperature, time and origin of raw materials (Çig dem Şentorun-Shalaby et al., 2006).

The activation temperature and the impregnation ratio have significant effects for the pore structure of the activated carbon (Dilek Angin et al., 2013). Activation atmosphere used in the chemical activation has an influence for the adsorption performance of activated carbons (Alicia Martínez de Yuso1 et al. 2014). The effect of pyrolysis temperature $\left(500\right.$ and $800{ }^{\circ} \mathrm{C}$ ) and activation method of cherry stones on the acid-base character of the surface can apply in the preparation of adsorbents with high capacity for nitrogen dioxide as well as different contaminants from the liquid phase (Piotr Nowicki, 2015). Chemical activation by $\mathrm{NaOH}$ is used for the obtaing a mainly of micropores with adsorbent properties (Alessandro C. Martins et al., 2015). A thermal treatment and a treatment with saturated urea solution also applied to the prepared activated carbons (Nunell G.V. et al., 2015). During activation by impregnation with different concentrations of $\mathrm{H}_{3} \mathrm{PO}_{4}, \mathrm{ZnCl}_{2}, \mathrm{HCl}$ were discovered that the increased concentration of $\mathrm{H}_{3} \mathrm{PO}_{4}$ from $10 \%$ to $40 \%$ impact to increase a density, a pore volume, a surface area and a lightening ability. Similarly, a mixture of $\mathrm{HCl}$ and $\mathrm{ZnCl}_{2}$ acts. It was concluded that a reasonable of obtaining the activated carbon from walnut shells with different kinds of characteristics (Khan A., 1985).

Agricultural and food-canning industry wastes, such as various fruit kernels have a wide application in the capacity of adsorbents for inorganic and organic compounds (Ioannidou O. \& Zabaniotou A., 2007; Martínez M.L. et al., 2006; Maryam Kazemipour et al., 2008). Granular activated carbon has great importance as adsorbents in the wastewater treatment, such as peat water treatment (Syafalni S. et al., 2013), a recycled pulp and paper mill factory effluents (Abu Bakar Mohamad et al., 2008). The adsorption of gold ions from industrial wastewater and removal of $\mathrm{Ni}$ (II) ions from aqueous solution using activated carbon derived from apricot shells has been studied by several authors (Mansooreh Soleimani et al., 2008; S. Erdoğan et al., 2005). The application of activated carbon in the adsorption process is mainly depends on the surface chemistry and pore structure of porous carbons (Anas Nahil M. and Williams P.T., 2012; Amit Bhatnagar et al. 2013). Different adsorption results are related with textural properties of activated carbons from apricot shells prepared by $\mathrm{H}_{3} \mathrm{PO}_{4}, \mathrm{ZnCl}_{2}$ and steam activation (A.M. Youssef et al. 2005). As well as adsorption capacity of $\mathrm{CO}_{2}$ and $\mathrm{H}_{3} \mathrm{PO}_{4}$ activated carbons are correlated by using methylene blues (Suresh Kumar Reddy et al. 2012). However, sometimes an increase in the temperature has a decrease in the yields of the activated carbons (Irem Okman et al. 2014).

All above-stated conclusions, experiments data, most of them currently have a significant value. They are fundamental in the solving of new problems, by creating adsorbents with desired properties. In the Republic of 
Kazakhstan, particularly important features are complex utilization of local wastes and obtaining on their basis the adsorbents with application in various spheres of national economy. In the Central Asian region, as well as in Kazakhstan fruit trees widely cultivate. The apricot kernel shells are the large-tonnage wastes of canned fruit productions, and fat-oil enterprises of fruit raw materials processing, in order to obtain the pharmacopoeia edible oil. In our opinion most perspective approach is the production of activated adsorbents from apricot stones, owing to a low cost, transportable, ecological compatibility and widely prevalence in the Central Asia region.

\section{Method}

\subsection{Study Methods}

For the study of the effect of thermal and chemical activation processes to the structural-sorption and physical-chemical characteristics of the apricot stones were used the classical and contemporary physical-chemical methods (Torosyan, 2010; Lutsik et al., 2008; Melchenko et al., 2005) that allowing to obtain a complete characterization of objects and on the theirs bases can be concluded the conformational state of the molecules, the different functional groups properties and the adsorbent adsorption properties. Further in the text for the replacing of the apricot stone or the apricot kernel shell is used a short word - the shell.

\subsection{Experimental Manipulations}

Differential thermal analysis was performed by the Q-derivative apparatus of MOM Company (Hungary). Elemental analysis was experimented by the analyzer EA-1108 of Carlo Erba Company (Italy). Photos of the porous structures of the apricot kernel shells were executed by the scanning electron microscope JSM-6490LV of JEOL (Japan). Dynamic and static activities of carbon in benzol were studied in accordance with the GOST 8703-74 (State Standard Specification (SSS) GOST 8703-74, 1974). The total pore volume was determined according to the GOST 17219-71 (State Standard Specification (SSS) GOST 17219-71, 1971). The volume of micropores, transitional pores and macropores of activated carbon was determined by the amount of adsorbed standard vapor (benzene), as well as a specific surface was identified according to the presented method (Kolyshkin D. A. \& Mikhaylova, 1972). Distribution of the pore sizes was determined by the penetration of hydrargyrum, based on measuring the volume of hydrargyrum that fills the pores with different hydrostatic pressures.

\subsection{Activation Approaches}

The process of grinding and mechanical activation of the apricot kernel shells was provided in the grinding mill and in the ball mill at the air and aquatic environments. For the chemical activation of the shells have used an apparatus that consists in the activation flask, electrical heater, backflow condenser and thermometer. Chemical activation was implemented by treatment with sulfuric, hydrochloric, phosphoric acids with a concentration of $5 \div 40 \%$ and zinc chloride by the penetration coefficient $0.1-0.6$. Then the samples were flushed by distilled water and dried at the $105^{\circ} \mathrm{C}$ in an oven for 2 hours. The shells were cooled in the exsiccator and placed in the flasks with rubber stoppers. The thermal activation was provided in a quartz furnace at the carbon dioxide atmosphere. Oven temperature was measured with a thermocouple of platinum-rhodium-platinum, regulated temperature control type ERM-47. The activation was carried out at the temperature of $300,400,500,600,700,800,900,1000{ }^{\circ} \mathrm{C}$ by soaking at each temperature for $1,2,3$, and 4 hours. Thermal treated samples were stored until the adsorption properties measurement in the airtightness medium.

\section{Results and Discussions}

\subsection{Thermal Analysis}

The analysis of thermogravimetric results shows (Figure 1) a mass losing till a temperature of $120^{\circ} \mathrm{C}$ because of moisture removing. Then in the temperature range from $120^{\circ} \mathrm{C}$ to $180^{\circ} \mathrm{C}$ shells do not undergo any transformations that change theirs mass. At the temperature $230{ }^{\circ} \mathrm{C}$ shells decomposition begins with extracting the volatile products that respectively accompanied by mass reducing. The total mass loss completes at the $690^{\circ} \mathrm{C}$.

The curve of differential-thermal analysis is characterized by a low endothermic effect at the $290{ }^{\circ} \mathrm{C}$, deep endothermic effect at the $400{ }^{\circ} \mathrm{C}$ and $430^{\circ} \mathrm{C}$. However, at the $360^{\circ} \mathrm{C}$ is observed an exothermic effect. Endothermic effect at the $287^{\circ} \mathrm{C}$ is related with the removal of hygroscopic moisture in small quantities - weight loss was $7.4 \%$. Substantial exothermic effect at the $360^{\circ} \mathrm{C}$ attributed to the beginning of burning organic impurities. Two deep endothermic effects at the $400{ }^{\circ} \mathrm{C}$ and $430{ }^{\circ} \mathrm{C}$ correspond to the decomposition of some hydroxyl organic compounds.

The differential-thermogravimetric analysis of shells assumes that on the basis of fixed endo- and exothermal effects during heating, interlayer water removes at the $120^{\circ} \mathrm{C}$. Then at the temperature of $230^{\circ} \mathrm{C}$ a dry distillation of carbon has begun. The volatile decomposition products have removed from the test sample with the maximum 
speed at the $270{ }^{\circ} \mathrm{C}$ and $300^{\circ} \mathrm{C}$. After these values, the speed of gas has decreased and stopped at the temperature of $690^{\circ} \mathrm{C}$.

By comparing the curves of differential-thermal and differential-thermogravimetric analyses, it was provided the estimation of the thermal reactions in the samples, simultaneously on both sides in terms of enthalpy and mass changes. Both curves show variations and their behaviors are different. This fact indicates that the curve of differential thermal analysis is formed by adding the thermal effects of several physical and chemical transformations. The curve of differential thermal analysis shows the resultant of these thermal effects with opposite sign. The origin of such a thermal effect is explained by the fact of break between the valence-force in organic compounds is accompanied by heat absorption, whereas recombination and formation of new compounds leads to the thermal generation. Endothermic effects are a specific for the curve of differential thermogravimetric analysis, or for the changing rate of the chemical valency bonds breaking and removal of gaseous fragments of $\mathrm{H}_{2}$, $\mathrm{CO}, \mathrm{CO}_{2}, \mathrm{CH}_{4}$.

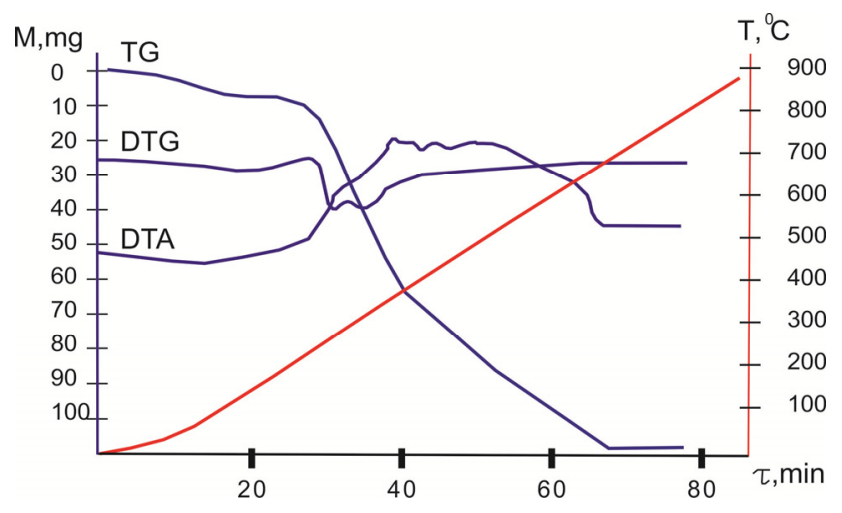

Figure 1. Derivatograms

TG - thermogravimetric analysis, DTA - differential thermal analysis, DTG - differential thermogravimetric analysis.

\subsection{Elemental Analysis}

According to the results of elemental analysis of organic compounds it was discovered that the shells consist of C $=74.856 \%, \mathrm{H}=24.754 \%$ and $\mathrm{N}=0.388 \%$ (Figure 2). Whereas a research the content of elements in the prunes kernels (Anurov et al. 2011) shows: $\mathrm{C}=54.1 \% ; \mathrm{H}=6.9 \% ; \mathrm{S}=0.3 \% ; \mathrm{N}=0.2 \% ; \mathrm{O}=38.5 \%$; in the walnut kernel shells: $\mathrm{C}=56.4 \% ; \mathrm{H}=6.5 \% ; \mathrm{S}=0.2 \% ; \mathrm{N}=0.3 \% ; \mathrm{O}=36.6 \%$. The shells considerably differ by own anatomical structure than timber. Strengthening tissues of apricot are consist of strong cells without fibrous form, and they a very thick lignified sheath and destroyed protoplast.

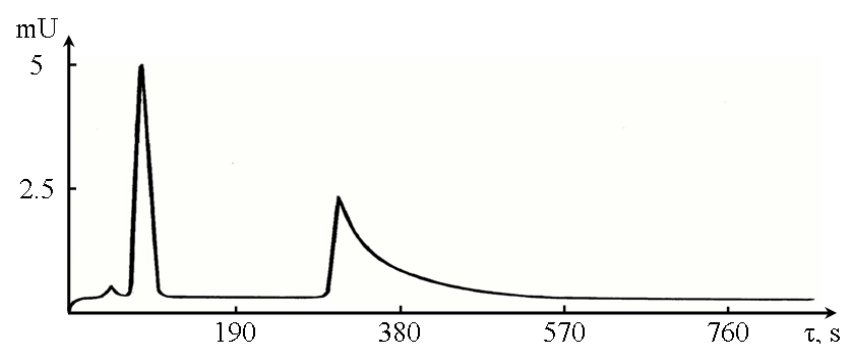

Figure 2. The distribution curve of organic materials for the apricot kernel shells

\subsection{Mechanical Activation of Apricot Kernels Shells}

Solids with very high specific surface area can be obtained by chemical methods, but the main methods of preparation of powders with an exposed surface are mechanical deformation and destruction. Different stages of 
these processes play an important role in the technology, because only the grinding of raw materials ensures a sufficiently a high reactivity from an economic vision. Mechanochemical destruction allows the solids activate and especially to increase their dispersion and significantly alter surface properties (Heinike 1984). Mechanochemical treatment of vanadium phosphate was performed in a planetary ball mill in air, water and ethanol mediums (Janusz et al. 2010). Activation in water and ethanol increases a specific surface area until $11 \mathrm{~m}^{2} / \mathrm{g}$ and pore volume of 0.39 $\mathrm{cm}^{3} / \mathrm{g}$. In the case of the influence of liquid additives, such as in water than air, the obtained surface will be a higher. The surface adsorbing or reacting with the solid substances during treatment often increases significantly as compared with grinding in an inert atmosphere. Under the influence of the environment decreases the surface energy of solids change their strength and plasticity (Rehbinder effect).

In our proposed process (Satayev et al. 2001) of obtaining activated carbon from fruit kernels provides a mechanical activation in the mechanical activator with subsequent chemical and thermal activation in the $\mathrm{CO}_{2}$ stream. For the increasing a porosity and specific surface of the shells, it has developed a device of mechanical activation, allowing with the most efficient to provide a mechanical activation process. Also to facilitate and reduce the energy and material expenses at a later stage of modification - chemical and thermal activations. The technical result of the invention consists in the improvement of the mechanical activity of materials.

The scheme of developed construction is illustrated in the Figure 3. It shows a general appearance of the device for the mechanical activation. In the Figure 4 are shown: beat, percussion elements and grooved surface. The device includes a frame, fixed beat elements, completed in the form of the polyhedron gear. The upper and lower chambers are interconnected with downpipes allow to regulate a supply of crushed material from one cell to another. At the bottom of the device a nozzle, for supply water to the activation camera, has installed. The grooving surfaces of the chamber walls and the rotating disks are located by grinding parties in against of each other. Bill and percussion elements have the form of the polyhedron gear.

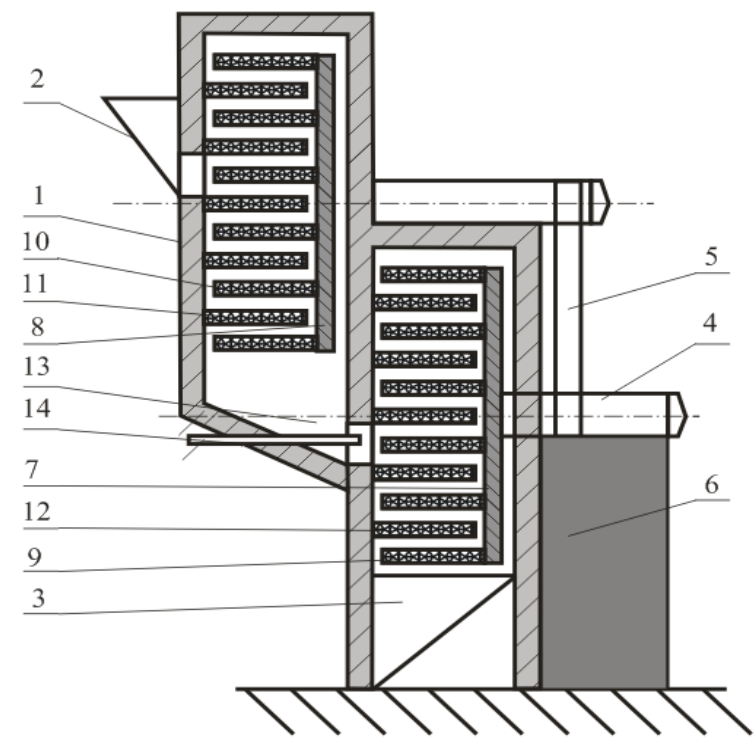

Figure 3. Device for the mechanical activation

1- frame, 2 - loading socket, 3- unloading socket, 4 - general gear, 5 -transmission gear, 6- column gear, 7 rotors with overhead camera discs, 8 - rotors with lower camera discs, 9 and 10 - beats, 11 and 12 - fixed percussion elements, 13- transfer gear, 14 - socket for water transmission to the activation camera.
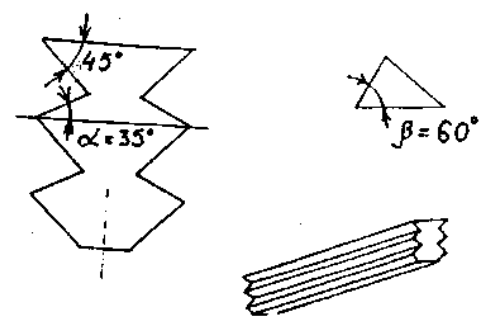

Figure 4. Beat, percussion elements and grooved surface of the device

The device operates as follows. The shells through the loading socket 2 enter to the upper center of the revolving 
rotor chamber 7. Under centrifugal force the shells do to the percussion elements 11 and beat 9 and corrugated surface of the chamber walls, cabble onto them and coming back to beat 9. During rotation 7 the chain percussion elements 11 and 9 form a grinding gap. The treated shells capture by grooved beat, then all passes through the grinding gap between beat and percussion elements, and they do to a number of underlying percussion elements and beat. Then the shells gradually move to the transfer gear 13, through that enter into the lower camera. Water supplies into the activation camera via socket 14 that is installed at the bottom of the device transfer unit. The process of mechanical activation in the lower camera is similar to the process in the upper camera, but the degree of activation is enhanced by water application (Rehbinder effect). The material moves through the beat rows 10 and percussion elements 12. Further it comes to the unloading socket 3 and it discharges from the device.

Manufacturing of beat and percussion elements in the form of the polyhedron gear ensures a high capture particulate material and the optimal trajectory of their flights. The presence of grooved surfaces on the beats, the percussion elements, the walls of the cameras and the rotating disks, it allows increasing the efficiency of mechanical activation of the shells. Such design of mechanical activator is suitable for obtaining high active surfaces and the desired dispersions of the shells. It provides next stages of modification: thermal or chemical activation.

Experimentally it was established that the increasing in deformation speed leads the decreasing in the plastic deformation zone. In the case of reach a certain limit the loading speed $(150 \mathrm{~m} / \mathrm{sec})$, the destruction has an explosive character that explains the considerable difference in energy expenses between the types of beat and compression (Figure 5). Specific energy consumption (energy per unit mass) at the same probability of destruction under material compression are more than multiply 10 then the same energy expended in the beat destruction. Increasing the loading rate impacts to an expansion in the difference of 20 or more multiplies. Significant energy inputs under static loading connected to the large volume of plastic deformation before destruction versus beat. The variation of energy consumption with speed increasing is more intense (Figure 5).

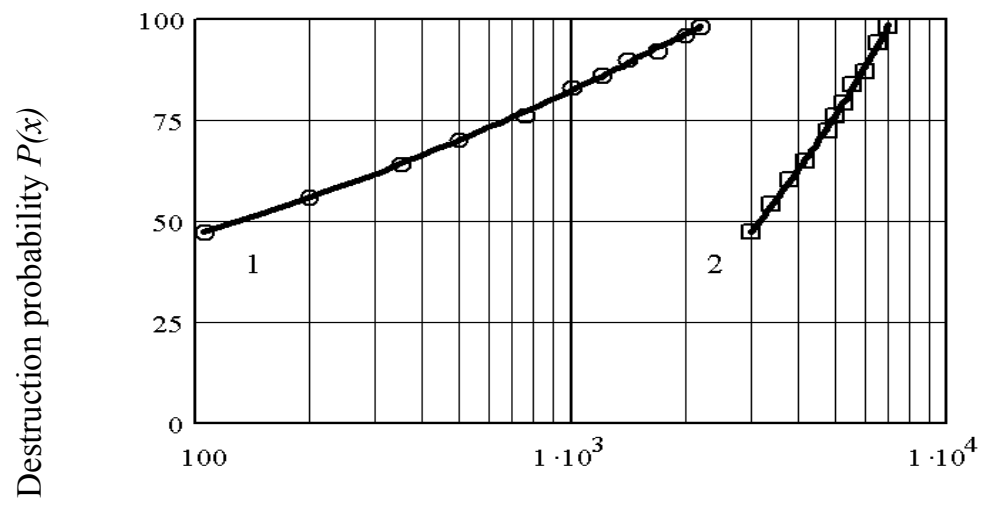

Energy inputs $E, \mathrm{Dj} / \mathrm{kg}$

Figure 5. Relation of the destruction probability and energy inputs

1 - beat; 2 - compression.

It was established that at low loading speeds the beat destruction is similar to the static compression. At high speeds, the destruction has the explosive nature of the formation of more uniform size pieces. The Figure 6 shows variations in microstructure of apricot kernel shells by different types of mechanical influences.
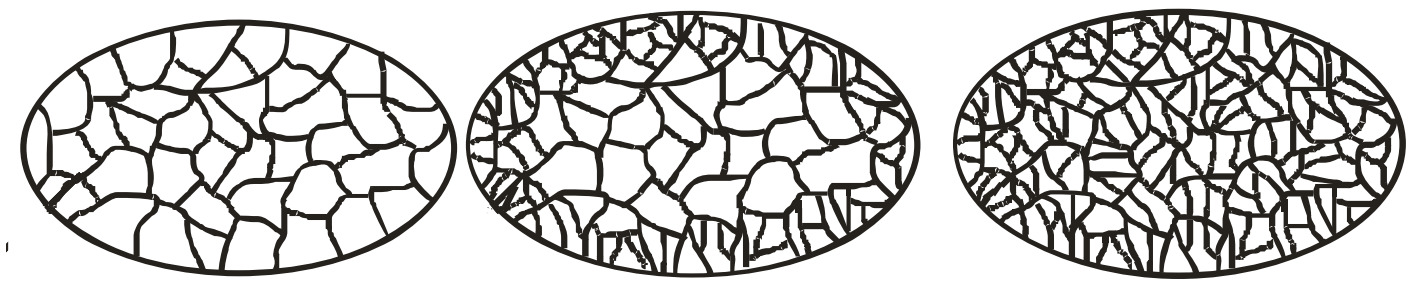

Figure 6. Variations in microstructure of apricot kernel shells by different types of mechanical influences 1 - initial shape; 2 - compression; 3 - beat. 
The difference between the destruction of nature imposes an imprint on the shape of the particles obtained after crushing the apricot kernel shells. For example, at the compression causes the formation of elongated particles and at the beat fragments have mainly the correct forms.

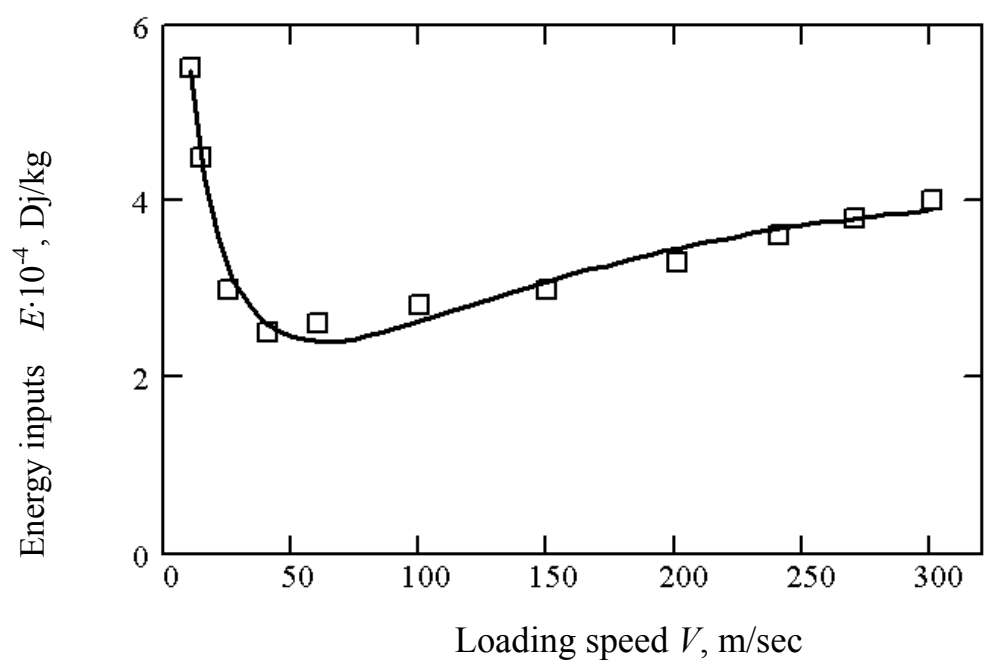

Figure 7. Relation of the energy inputs and the loading speed

Results of these experiments are important and have significant value in the task of active adsorbents modeling with desired properties. The proposed method of mechanical activation in the water presence is preferred for very high active surfaces and the desired dispersions of the shells, for providing further stages of thermal and chemical activation used in the obtaining of porous with specific areas.

\subsection{Thermal Activation of Apricot Kernel Shells}

Parameters of the porous structure of activated carbon (AAK1 - apricot activated kernels), obtained by thermal activation of apricot kernel shells are shown in Figure 8. The temperature increasing from $300{ }^{\circ} \mathrm{C}$ to $500{ }^{\circ} \mathrm{C}$ impacts to a low development of porous structure, with a total pores volume is from 3.8 to $5.0 \cdot 10^{-4} \mathrm{~m}^{3} / \mathrm{kg}$. The expansion in activation temperature from $600{ }^{\circ} \mathrm{C}$ to $700^{\circ} \mathrm{C}$ is accompanied by increasing the pores volume until the maximum value $\left(8.5-11.0 \cdot 10^{-4}\right) \mathrm{m}^{3} / \mathrm{kg}$. Further increasing in temperature from $800{ }^{\circ} \mathrm{C}$ to $1000{ }^{\circ} \mathrm{C}$ do unfavorable affect for the quality of activated carbon, because contained gums and hydrocarbons are decomposed with the formation of inactive carbon accumulates on the surface of the coal, also it brings the pores sintering.

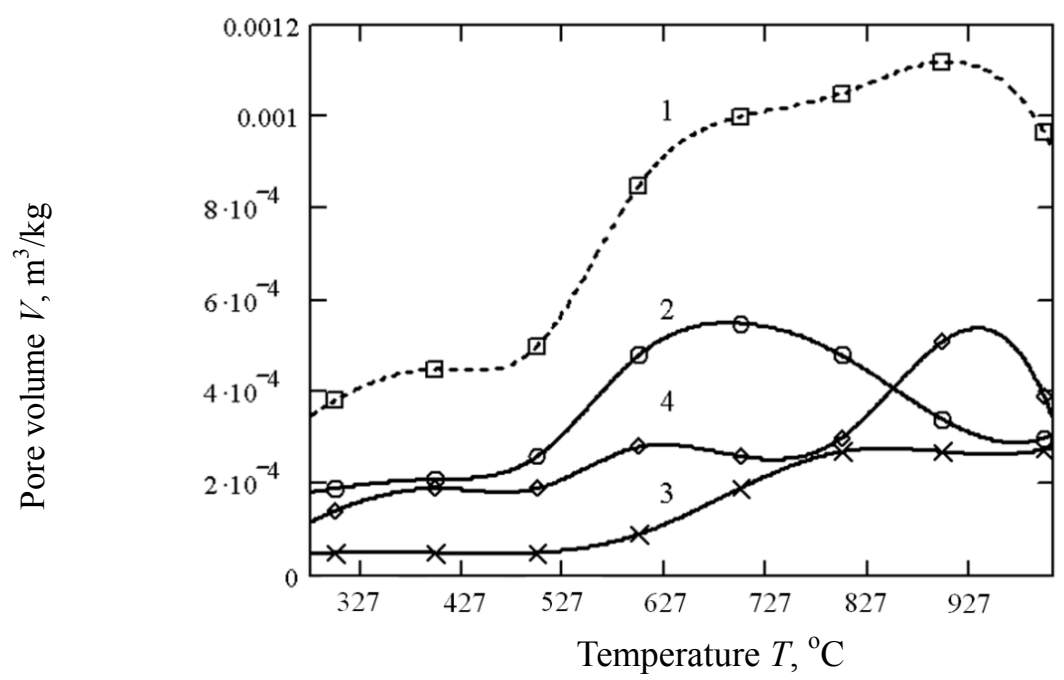

Figure 8. Influence of thermal activation temperature into $\mathrm{CO}_{2}$ stream for the shells pores volume 1 - total pores volume, 2 - micropores, 3 - mesopores, 4 - macropores. 
The table 1 shows the characteristics of the obtaining activated carbon (AAK1) from the apricot kernel shells, as well as in comparison with the known types of adsorbents A2PS-1, KAU-1, SCN-4 (Skubiszewska-Zieba, 2011), walnuts kernels (WK) (Anurov, 2011), and plum kernels (PK) (Anurov, 2011).

Table 1. Characteristics of the porous structure of activated carbons obtained by thermal activation

\begin{tabular}{|c|c|c|c|c|c|}
\hline Sample & $\begin{array}{l}\text { Sample treatment } \\
\text { terms }\end{array}$ & $\begin{array}{c}\text { Volume of } \\
\text { total pore, } \\
V_{t}, 10^{-4} \\
\mathrm{~m}^{3} / \mathrm{kg}\end{array}$ & $\begin{array}{c}\text { Volume of } \\
\text { micropores, } \\
V_{m i c}, 10^{-4} \\
\mathrm{~m}^{3} / \mathrm{kg}\end{array}$ & $\begin{array}{c}\text { Volume of } \\
\text { mesopore, } \\
V_{m e s}, 10^{-4} \\
\mathrm{~m}^{3} / \mathrm{kg}\end{array}$ & $\begin{array}{c}\text { Volume of } \\
\text { macropores, } \\
V_{m a c}, 10^{-4} \\
\mathrm{~m}^{3} / \mathrm{kg}\end{array}$ \\
\hline $\begin{array}{lll}\text { Apricot } & \text { kernel } & \text { shells } \\
\text { (AAK1) } & & \end{array}$ & $\mathrm{CO}_{2}, 700^{\circ} \mathrm{C}$ & 10.0 & 5.5 & 1.9 & 2.6 \\
\hline $\begin{array}{l}\text { Plum kernel shells (A2PS-1) } \\
\text { (Martinez et al., 2003) }\end{array}$ & Water, $250^{\circ} \mathrm{C}$ & 9.69 & 5.08 & 2.46 & 2.15 \\
\hline $\begin{array}{l}\text { KAU-1 (Martinez et al., } \\
\text { 2003) }\end{array}$ & Water, $400^{\circ} \mathrm{C}$ & 4.8 & 3.3 & 1.2 & - \\
\hline $\begin{array}{l}\text { SCN-4 (Martinez et al., } \\
\text { 2003) }\end{array}$ & Water, $350{ }^{\circ} \mathrm{C}$ & 4.61 & 1.57 & 1.10 & 1.94 \\
\hline $\begin{array}{l}\text { Walnut kernels (WK) } \\
\text { (Anurov et al. 2011) }\end{array}$ & Nitrogen, $800^{\circ} \mathrm{C}$ & - & 2.2 & - & - \\
\hline $\begin{array}{l}\text { Plum kernel (PK) (Anurov et } \\
\text { al., 2011) }\end{array}$ & Nitrogen, $800^{\circ} \mathrm{C}$ & 2.9 & 2.0 & 0.4 & 0.5 \\
\hline
\end{tabular}

Figure 9 shows photographs of the porous structures of the apricot kernel shells in comparison with the walnut kernels and peach kernels (Martinez et al., 2003) and cashew nut kernels (Tangjuank et al., 2009). Images obtained by electron microscopy of activated carbon from walnut kernels (Martinez et al., 2003) (Figure 9a) show the average size of micropores between $8.05 \cdot 10^{-4} \mu \mathrm{m}$ and $2.13 \cdot 10^{-4} \mu \mathrm{m}$. For activated carbon from the peach kernels (Figure 9b) were $7.29 \cdot 10^{-3} \mu \mathrm{m}$ for mesopores and $3.73 \cdot 10^{-4} \mu \mathrm{m}$ for the micropores. Activated carbon obtained from walnut kernels shows a heterogeneous structure with smaller pores than those of the peach kernels. Activation of the sample (cashew nut kernels) (Tangjuank et al., 2009) (Figure 9c) for KOH/Char equal to 1 produced the irregular structure with rough texture and a large number of shallow cavities on the surface. Furthermore, the SEM result shows that the activated carbon appears to have well developed macropores of the order of 10-30 $\mu \mathrm{m}$. Microstructures SEM of chemical activation of apricot kernel shells (Figure 9d) shows typical structure, most of pores appears in the inter pores areas. During chemical activation the surface was destructed by powerful $\mathrm{ZnCl}_{2}$ activation, in result there were formed pores and occurrence the cell configuration.

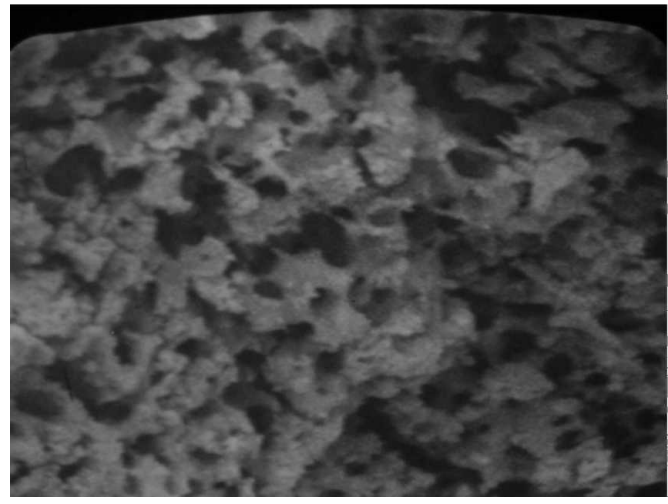

a: Activated carbons from walnut kernels

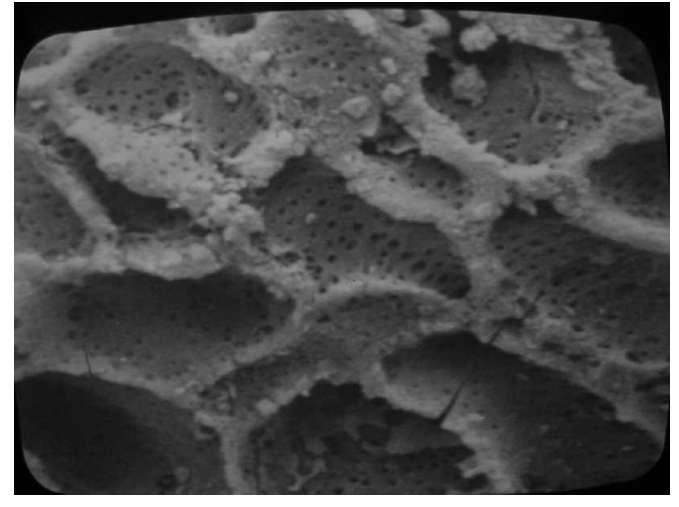

b: Activated carbons from peach kernels 


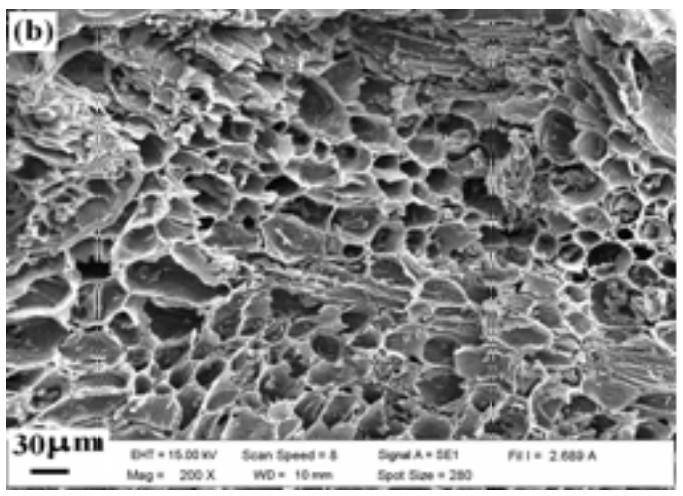

c: Activated carbons from cashew nut kernels;

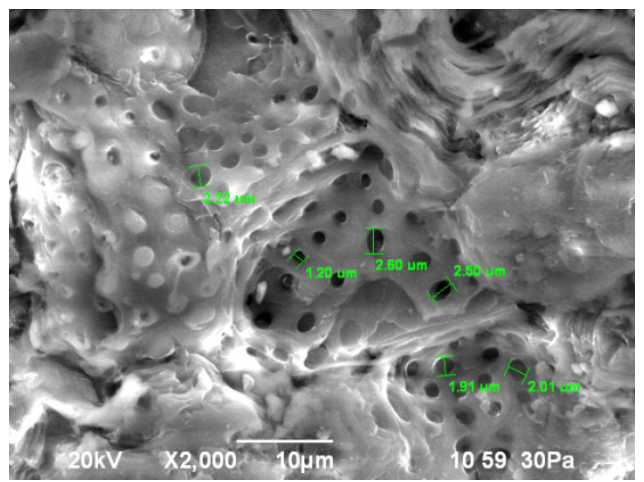

d: Activated carbons from apricot kernels

(b) $\mathrm{KOH} / \mathrm{Char}=1$ with activation time $20 \mathrm{~min}$

Figure 9. Pores structure photos: (a) walnut kernels (Martinez et al., 2003), (b) peach kernels (Martinez et al., 2003), (c) cashew nut kernels (Tangjuank et al., 2009) and (d) apricot kernel

Table 2 summarizes the main characteristics of the porosity, therewith the structure constants $B$ and $W_{0}$ in the equations of the micropores theory volume filling. The constant $B$ characterizes the size of the micropores, $W_{0}$ the maximum amount of adsorption space. The data table shows that at the constant $B$ with low values the value of $W_{0}$ is closed to the volume of micropores. The increasing of constant $B$ indicates with grow of micropores sizes. The difference in the total pore volume and the static activity of benzol, interprets by the presence of small pores that are inaccessible for larger benzol molecules.

Table 2. Main characteristics of the modified activated carbon (AAK1)

\begin{tabular}{llllll}
\hline $\begin{array}{l}\text { Activation } \\
\text { temperature } \\
T,{ }^{\circ} \mathrm{C}\end{array}$ & $\begin{array}{l}\text { Activation } \\
\text { time } \\
\tau, \text { hours }\end{array}$ & $\begin{array}{l}\text { Total pore volume } \\
V_{t}, 10^{-4} \mathrm{~m}^{3} / \mathrm{kg}\end{array}$ & $\begin{array}{l}\text { Statistical activity by benzol } \\
a_{s}, 10^{-4} \mathrm{~m}^{3} / \mathrm{kg}\end{array}$ & $\begin{array}{l}\text { Structure constants } \\
W_{0}, 10^{-4} \mathrm{~m}^{3} / \mathrm{kg}\end{array}$ & $B \cdot 10^{6}$ \\
\hline 600 & 3 & 8.5 & & 4.8 & 0.71 \\
700 & 3 & 10.0 & 2.8 & 5.4 & 0.88 \\
700 & 4 & 11.0 & 3.1 & 5.8 & 1.05 \\
800 & 3 & 10.5 & 2.9 & 4.8 & 0.84 \\
\hline
\end{tabular}

Thus, experimental results show the effectiveness of thermal treatment of apricot kernel shells that have a large volume of micropores and transitional porosity moderately developed, providing the intensity of the adsorbate diffusion into the grain of the adsorbent.

\subsection{Chemical Activation of Apricot Kernel Shells}

The process of chemical activation of adsorbents of natural origin - one of the most important processes for obtaining high-quality activated carbons used in various industries. In the case of adsorption from solutions of substances with large molecules, for which the micropores are virtually impossible then the main importance is the surface of transitional pores. Due to the purpose of this chapter is the study of the characteristics of chemically-activated apricot kernel shells.

The parameters of the porous structure of activated carbons (AAK2) from the apricot kernel shells were activated by sulphuric acid $\left(\mathrm{H}_{2} \mathrm{SO}_{4}\right)$ at the concentrations: 5, 10, 15, 20, 30 and 40(\%) during 1-4 (hours) are shown in Figure 10.

The growth of the activator concentration factor of 4 resulted the short increase in the total pores volume $4.7 \cdot 10^{-4}$ $\mathrm{m}^{3} / \mathrm{kg}$ and a porous structure. Increasing in the concentration of sulphuric acid until $30 \%$ accompanied by an expansions of micropores $2.3 \cdot 10^{-4} \mathrm{~m}^{3} / \mathrm{kg}$ and mesopores $2.6 \cdot 10^{-4} \mathrm{~m}^{3} / \mathrm{kg}$. A further increase in concentration has a insignificantly effect to the total pores volume $6.6 \cdot 10^{-4} \mathrm{~m}^{3} / \mathrm{kg}$ and a porous structure. With the processing time prolongation by the sulphuric acid concentration of $30 \%$ until 2 hours a total porosity expansions from $5.0 \cdot 10^{-4}$ $\mathrm{m}^{3} / \mathrm{kg}$ to $6.5 \cdot 10^{-4} \mathrm{~m}^{3} / \mathrm{kg}$, and the increasing the processing time from 3 to 4 hours, insignificantly affect to the total pores volume $6.6 \cdot 10^{-4} \mathrm{~m}^{3} / \mathrm{kg}$. 


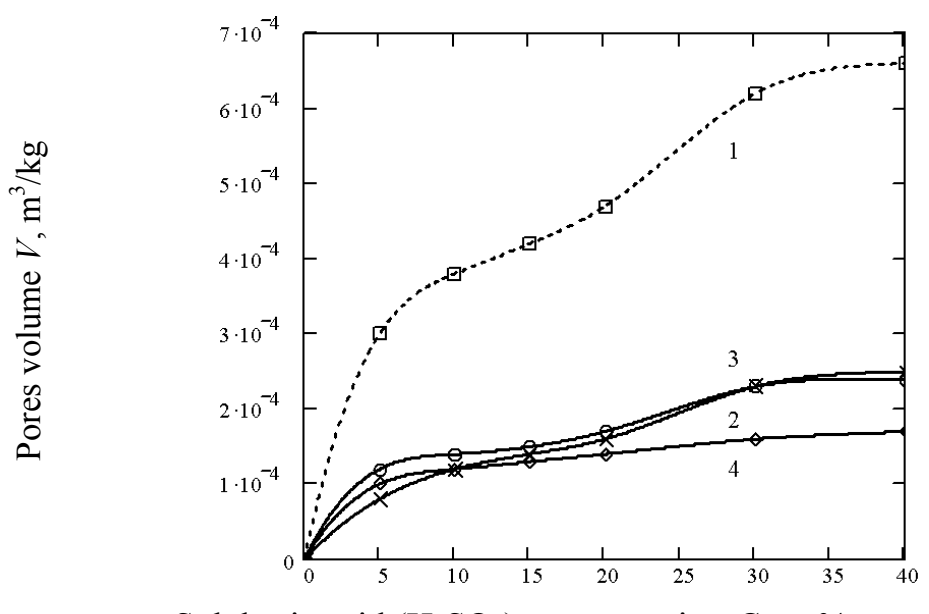

Sulphuric acid $\left(\mathrm{H}_{2} \mathrm{SO}_{4}\right)$ concentration $C_{\text {acid }} \%$

Figure 10. Influence of concentration of sulphuric acid $\left(\mathrm{H}_{2} \mathrm{SO}_{4}\right)$ at the chemical activation for the shells pores volume

1 - total pores volume, 2 - micropores, 3 - mesopores, 4 - macropores.

The parameters of the porous structure of activated carbons (AAK3) from the apricot kernel shells activated by hydrochloric acid $(\mathrm{HCl})$ at the concentrations: 5, 10, 15, 20, 30 and $40(\%)$ during 1-4 (hours) are shown in Figure 11. The Figure shows that increasing the concentration of hydrochloric acid from $5 \%$ to $20 \%$ attracts to the low development of the porous structure (total pores volume vary from $2.7 \cdot 10^{-4} \mathrm{~m}^{3} / \mathrm{kg}$ to $4.2 \cdot 10^{-4} \mathrm{~m}^{3} / \mathrm{kg}$ The increasing of the concentration from $30 \%$ to $40 \%$ impacts a weak development of the porous structure and a total pores volume of $4.9 \cdot 10^{-4} \mathrm{~m}^{3} / \mathrm{kg}$ to $6.2 \cdot 10^{-4} \mathrm{~m}^{3} / \mathrm{kg}$. The processing time prolongation by hydrochloric acid at the 3 to 4 hours almost is not effected for the pores volume.

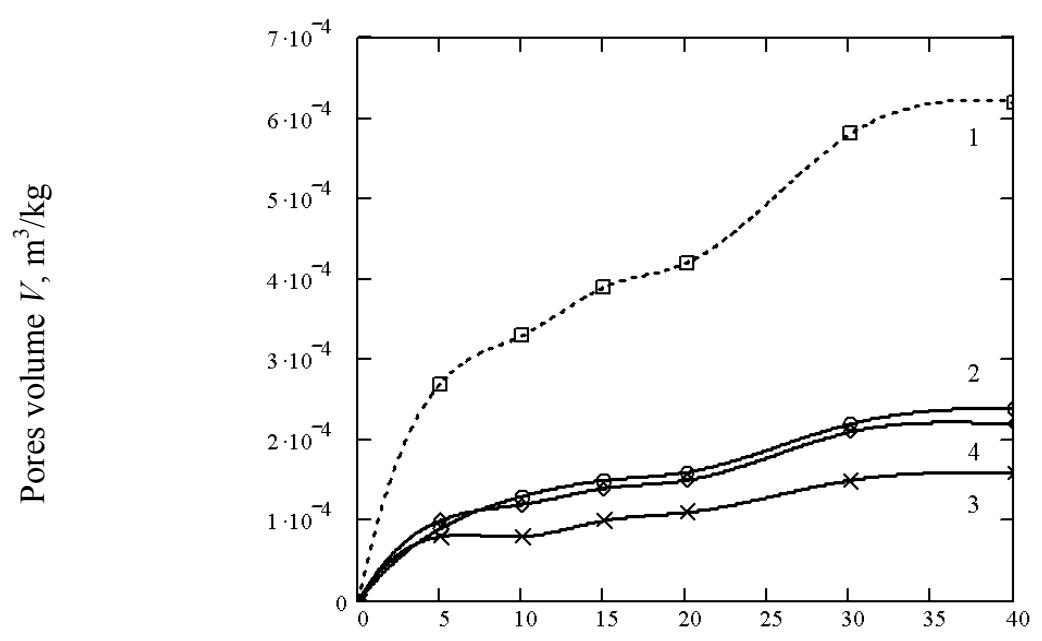

Hydrochloric acid ( $\mathrm{HCl})$ concentration $C_{a c i d}, \%$

Figure 11. Influence of concentration of hydrochloric acid $(\mathrm{HCl})$ at the chemical activation for the shells pores volume

1 - total pore volume, 2 - micropores, 3 - mesopores, 4 - macropores.

The parameters of the porous structure of activated carbons (AAK4) from the apricot kernel shells activated by phosphoric acid $\left(\mathrm{H}_{3} \mathrm{PO}_{4}\right)$ at the concentrations: 5, 10, 15, 20, 30 and 40\% during $1 \div 4$ (hours) are shown in Figure 11. These data show that the development of porous structure is similar to the processing of sulphuric and hydrochloric acids, but with smaller pores volume. Increasing the concentration of phosphoric acid from $5 \%$ to $20 \%$ has little effect on the total pore volume $2.5 \cdot 10^{-4} \mathrm{~m}^{3} / \mathrm{kg}$, and increasing the concentration from $30 \%$ to $40 \%$ as poorly developed overall porosity $4.5 \cdot 10^{-4} \mathrm{~m}^{3} / \mathrm{kg}$. Extension the processing time with phosphoric acid from 1 to 4 hours had a little effect for the porosity (in the beginning of treatment of $3.1 \cdot 10^{-4} \mathrm{~m}^{3} / \mathrm{kg}$, after $4.5 \cdot 10^{-4}$ $\left.\mathrm{m}^{3} / \mathrm{kg}\right)$. 


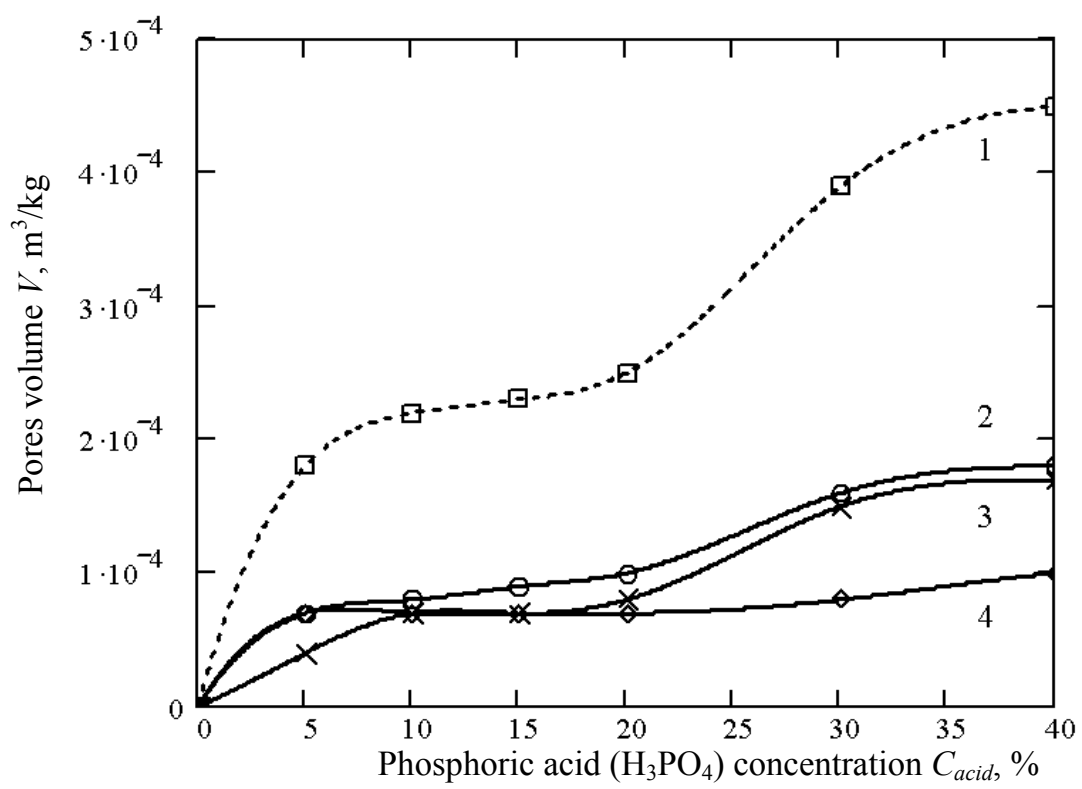

Figure 12. Influence of econcentration of phosphoric acid $\left(\mathrm{H}_{3} \mathrm{PO}_{4}\right)$ at the chemical activation for the shells pores volume

1 - total pore volume, 2 - micropores, 3 - mesopores, 4 - macropores.

The parameters of the porous structure of activated carbons (AAK5) from the apricot kernel shells activated by zinc chloride $\left(\mathrm{ZnCl}_{2}\right)$ with a coefficient of impregnation (ratio of activator to the anhydrous mass of dry natural source material), 0.1, 0.2, 0.3, 0.4, 0.5, 0.6 for $1-4$ (hours) are shown in Figure 12. At the increasing impregnation coefficient from 0.1 to 0.4 the coal porosity develops and thereby it increases the total pores volume of $4.9 \cdot 10^{-4}$ $\mathrm{m}^{3} / \mathrm{kg}$ to $9.8 \cdot 10^{-4} \mathrm{~m}^{3} / \mathrm{kg}$. At the value of the coefficient of impregnation of 0.5 to 0.6 the volume of micropores decreases from $2.5 \cdot 10^{-4} \mathrm{~m}^{3} / \mathrm{kg}$ to $2.0 \cdot 10^{-4} \mathrm{~m}^{3} / \mathrm{kg}$ and mesopore volume of $6.0 \cdot 10^{-4} \mathrm{~m}^{3} / \mathrm{kg}$ to $3.9 \cdot 10^{-4} \mathrm{~m}^{3} / \mathrm{kg}$ and begins the development of microporosity $1.3 \cdot 10^{-4} \mathrm{~m}^{3} / \mathrm{kg}$ to $2.2 \cdot 10^{-4} \mathrm{~m}^{3} / \mathrm{kg}$. For the impregnation coefficient 0.4 activation duration equal to one hour of poorly developed total pore volume $\left(6.3 \cdot 10^{-4} \mathrm{~m}^{3} / \mathrm{kg}\right)$. The ascent in activation time from 2 hours to 4 hours increases a total pores volume of $7.2 \cdot 10^{-4} \mathrm{~m}^{3} / \mathrm{kg}$ to $9.8 \cdot 10^{-4} \mathrm{~m}^{3} / \mathrm{kg}$ and mesopore volume of $4.8 \cdot 10^{-4} \mathrm{~m}^{3} / \mathrm{kg}$ to $5.7 \cdot 10^{-4} \mathrm{~m}^{3} / \mathrm{kg}$.

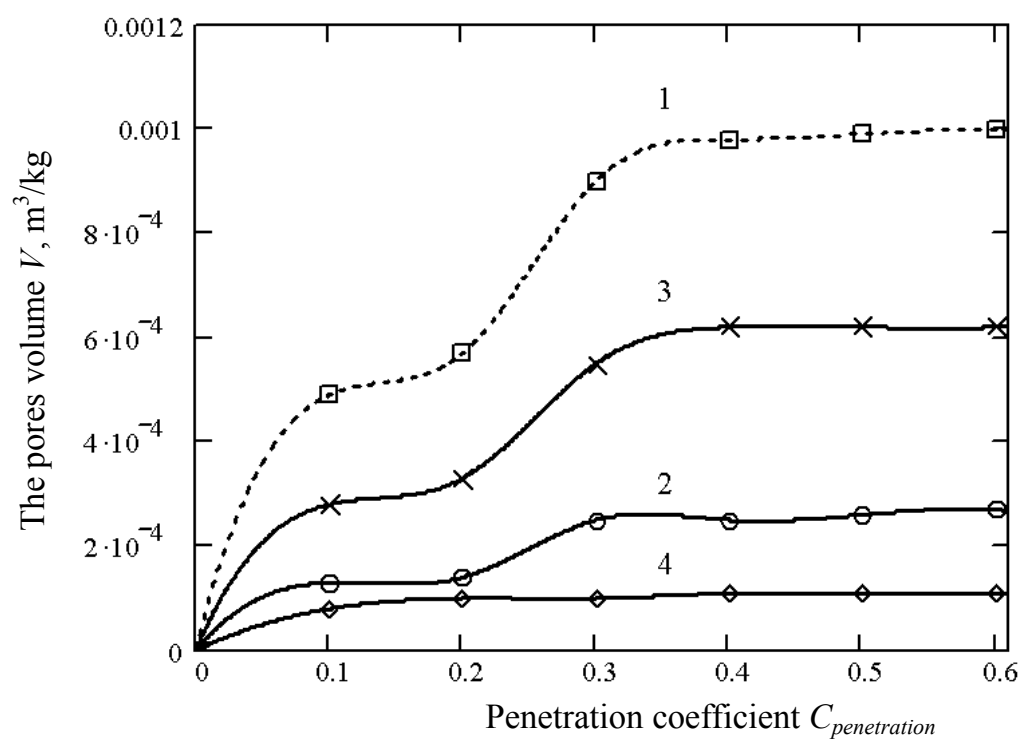

Figure 13. Influence of penetration coefficient by zinc chloride $\left(\mathrm{ZnCl}_{2}\right)$ at the chemical activation for the shells pores volume

1 - total pores volume, 2 - micropores, 3 - mesopores, 4 - macropores. 
The parameters of the porous structure of activated carbons (AAK6) from the apricot kernel shells activated by zinc chloride $\left(\mathrm{ZnCl}_{2}\right)$ with penetration coefficient of $0.2,0.3,0.4,0.5,0.6$, with subsequent activation in a quartz furnace in an atmosphere of carbon dioxide $\left(\mathrm{CO}_{2}\right)$ at the temperatures from $573 \mathrm{~K}$ to $873 \mathrm{~K}$ are shown in table 3 . As well as in the previous example, in this case with increasing penetration ratio from 0.2 to 0.4 is the development the coal porosity, and thereby increases the total pore volume of $6.8 \cdot 10^{-4} \mathrm{~m}^{3} / \mathrm{kg}$ to $12.0 \cdot 10^{-4} \mathrm{~m}^{3} / \mathrm{kg}$. If the value of the penetration coefficient of 0.5 to 0.6 decreases the volume of micropores from $4.0 \cdot 10^{-4} \mathrm{~m}^{3} / \mathrm{kg}$ to $3.0 \cdot 10^{-4} \mathrm{~m}^{3} / \mathrm{kg}$ and mesopore volume of $5.5 \cdot 10^{-4} \mathrm{~m}^{3} / \mathrm{kg}$ to $5.0 \cdot 10^{-4} \mathrm{~m}^{3} / \mathrm{kg}$ and begins development of macroporosity $1.5 \cdot 10^{-4} \mathrm{~m}^{3} / \mathrm{kg}$ to $2.0 \cdot 10^{-4} \mathrm{~m}^{3} / \mathrm{kg}$. Penetration with the coefficient 0.4 increases at the temperature from $573 \mathrm{~K}$ to $773 \mathrm{~K}$ brings for a significant development of the porous structure (total pore volume of $7.0 \cdot 10^{-4}$ $\mathrm{m}^{3} / \mathrm{kg}$ to $12.0 \cdot 10^{-4} \mathrm{~m}^{3} / \mathrm{kg}$ ). Further increase in the temperature until $873 \mathrm{~K}$ affects the porous structure that in result decrease in micropore volume of $4.2 \cdot 10^{-4} \mathrm{~m}^{3} / \mathrm{kg}$ to $4.0 \cdot 10^{-4} \mathrm{~m}^{3} / \mathrm{kg}$ and mesopore volume of $6.5 \cdot 10^{-4} \mathrm{~m}^{3} / \mathrm{kg}$ to $5.7 \cdot 10^{-4} \mathrm{~m}^{3} / \mathrm{kg}$.

Table 3. Parameters of porous structure of the modified activated carbon that received by chloride of zinc $\left(\mathrm{ZnCl}_{2}\right)$ activation with the subsequent activation in the quartz furnace in the carbonic gas $\left(\mathrm{CO}_{2}\right)$ atmosphere

\begin{tabular}{llllll}
\hline Temperature $T, \mathrm{~K}$ & $\begin{array}{l}\text { Penetration } \\
\text { coefficient }\end{array}$ & $\begin{array}{l}\text { Volume of total } \\
\text { pore, } \\
V_{t}, \quad 10^{4} \mathrm{~m}^{3} / \mathrm{kg}\end{array}$ & $\begin{array}{l}\text { Volume of } \\
\text { micropores, } \\
V_{\text {mic }}, 10^{4} \mathrm{~m}^{3} / \mathrm{kg}\end{array}$ & $\begin{array}{l}\text { Volume } \\
\text { mesopores, } \\
V_{\text {mes }}, 10^{4} \mathrm{~m}^{3} / \mathrm{kg}\end{array}$ & $\begin{array}{l}\text { of } \\
\text { macropores, } \\
V_{\text {mac }}, 10^{4} \mathrm{~m}^{3} / \mathrm{kg}\end{array}$ \\
\hline 773 & 0.8 & 6.8 & 3.7 & 2.5 & 0.6 \\
773 & 0.3 & 8.0 & 4.0 & 2.7 & 1.3 \\
573 & 0.4 & 7.0 & 2.1 & 3.2 & 1.7 \\
673 & 0.4 & 9.0 & 3.0 & 4.5 & 1.5 \\
773 & 0.4 & 12.0 & 4.2 & 6.5 & 1.3 \\
873 & 0.4 & 11.0 & 4.0 & 5.7 & 1.3 \\
773 & 0.5 & 11.0 & 4.0 & 5.5 & 1.5 \\
773 & 0.6 & 10.0 & 3.0 & 5.0 & 2.0 \\
\hline
\end{tabular}

Table 4 shows the characteristics of activated carbons derived activated carbon (AAK6) from the apricot kernel shells activated by zinc chloride $\left(\mathrm{ZnCl}_{2}\right)$ with subsequent activation of carbon dioxide $\left(\mathrm{CO}_{2}\right)$ in comparison with A2PS-5, KAU-2, SCN-5 (Skubiszewska-Zieba, 2011), apricot kernels (Strelko et al., 1996), as well as walnut kernels (Zabihi et al., 2010).

The study of sorption of methylene blue for determinate the exchange capacity and the specific surface derived activated carbons, we have provided on selected samples on the analysis above mentioned Figures. The studies were conducted at a ratio of adsorbent and absorbate equal to 1:200 (table 5). The experimental data assume that the adsorption of methylene blue may be used only for the approximate determination of the specific surface area, i.e. study the adsorption of the dye can be estimated to assess the external surface of the adsorbent. Comparative studies of adsorption of methylene blue from aqueous solution by activated animal charcoal (CPAC), sawdust (SDZ) and walnut (WNSZ), activated $\mathrm{ZnO}$ have showed that the adsorption capacity at CPAC by more developed specific surface area (Abechi et al., 2006). SDZ adsorbent on the adsorption of methylene blue superior WNSZ.

Table 4. Characteristics of the porous structure of activated carbons obtained by chemical and thermal activations

\begin{tabular}{|c|c|c|c|c|c|}
\hline Sample & $\begin{array}{l}\text { Sample treatment } \\
\text { terms }\end{array}$ & $\begin{array}{l}\text { Volume of } \\
\text { total pore, } \\
V_{t}, \quad 10^{4} \\
\mathrm{~m}^{3} / \mathrm{kg} \\
\end{array}$ & $\begin{array}{l}\text { Volume of } \\
\text { micropores, } \\
V_{m i c}, \quad 10^{4} \\
\mathrm{~m}^{3} / \mathrm{kg}\end{array}$ & $\begin{array}{l}\text { Volume of } \\
\text { mesopores, } \\
V_{\text {mes }}, 10^{4} \mathrm{~m}^{3} / \mathrm{kg}\end{array}$ & $\begin{array}{l}\text { Volume of } \\
\text { macropores, } \\
V_{\text {mac }}, 10^{4} \mathrm{~m}^{3} / \mathrm{kg}\end{array}$ \\
\hline $\begin{array}{l}\text { Apricot kernel shells } \\
\text { (AAK6) }\end{array}$ & $\begin{array}{l}\mathrm{ZnCl}_{2}, \quad \text { penetration } \\
\text { coefficient } \\
773 \mathrm{~K}\end{array}$ & 12.0 & 4.2 & 6.5 & 1.3 \\
\hline $\begin{array}{l}\text { Plum kernels } \\
\text { (A2PS-5) } \\
\text { (Skubiszewska-Zieba }\end{array}$ & $20 \% \mathrm{H}_{2} \mathrm{O}_{2}, 250^{\circ} \mathrm{C}$ & 9.61 & 4.4 & 2.46 & 2.72 \\
\hline
\end{tabular}




\begin{tabular}{|c|c|c|c|c|c|}
\hline et al., 2011) & & & & & \\
\hline $\begin{array}{l}\text { KAU-2 } \\
\text { (Skubiszewska-Zieba } \\
\text { et al., 2011) }\end{array}$ & $\begin{array}{l}\text { Single HTT } 30 \% \\
\mathrm{H}_{2} \mathrm{O}_{2}, 350^{\circ} \mathrm{C}\end{array}$ & 5.4 & 2.8 & 1.6 & - \\
\hline $\begin{array}{l}\text { SCN-5 } \\
\text { (Skubiszewska-Zieba } \\
\text { et al., 2011) }\end{array}$ & $20 \% \mathrm{H}_{2} \mathrm{O}_{2}, 250^{\circ} \mathrm{C}$ & 6.59 & 1.85 & 1.60 & 3.13 \\
\hline $\begin{array}{l}\text { Apricot kernels } \\
\text { (Strelko et al., 1996) }\end{array}$ & $\begin{array}{l}\mathrm{NaOH} \text { solution with } \\
\text { steam at the } 850{ }^{\circ} \mathrm{C}\end{array}$ & - & 4.2 & 4.6 & 3.5 \\
\hline $\begin{array}{l}\text { Walnut kernels } \\
\text { (Carbon A) } \\
\text { (Strelko et al., 1996) }\end{array}$ & $\begin{array}{l}\left(\text { Shells : } \mathrm{ZnCl}_{2}\right) \\
\text { mass ratio } 1: 0.5, \\
\text { carbonization in } \mathrm{N}_{2} \\
\text { stream }\end{array}$ & 4.26 & - & - & - \\
\hline $\begin{array}{l}\text { Walnut kernels } \\
\text { (Carbon B) } \\
\text { (Zabihi et al., 2010) }\end{array}$ & $\begin{array}{l}\text { Shells : } \mathrm{ZnCl}_{2} \text { ) mass } \\
\text { ratio } 1: 1 \text {, } \\
\text { carbonization in } \mathrm{N}_{2} \\
\text { stream }\end{array}$ & 3.87 & - & - & - \\
\hline
\end{tabular}

Surface modification of the sample affects to the change of the pores space that depends on the adsorption capacity of activated carbon. At the same time is important to select an individual approach for the each sorbent by taking to account a structure, a size and porosity (Satayev et al., 2012). In the adsorbents transitional pores at high pressures the phase transition occurs by the mechanism of capillary condensation.

Table 5. Methylene blue adsorption by modified activated carbons

\begin{tabular}{lcccc}
\hline \multicolumn{1}{c}{ Adsorbent } & $\begin{array}{l}\text { Initial } \\
\text { concentration } \\
C_{o}, \mathrm{~kg} / \mathrm{m}^{3}\end{array}$ & $\begin{array}{l}\text { Final } \\
\text { concentration } \\
C_{x}, \mathrm{~kg} / \mathrm{m}^{3}\end{array}$ & $\begin{array}{l}\text { Adsorption } \\
\text { value } A, \\
\mathrm{~kg} / \mathrm{m}^{3}\end{array}$ & $\begin{array}{l}\text { Specific surface } \\
\mathrm{S}, \mathrm{m}^{2} / \mathrm{g} \cdot 10^{4} \\
\text { by MB }\end{array}$ \\
\hline $\begin{array}{l}\text { Activated by } 30 \% \text { hydrochloric acid }(\mathrm{HCl}) \\
\text { during 2 hours. }\end{array}$ & 0.61 & 0.355 & 0.051 & 4.47 \\
$\begin{array}{l}\text { Activated by 30\% sulfuric acid }\left(\mathrm{H}_{2} \mathrm{SO}_{4}\right) \\
\text { during 2 hours. }\end{array}$ & 0.6 & 0.36 & 0.048 & 8.4 \\
$\begin{array}{l}\text { Activated by zinc chloride }\left(\mathrm{ZnCl}_{2}\right) \\
\text { (impregnation ratio -0.4; time - 3 hours) }\end{array}$ & 0.55 & 0.155 & 0.079 & 11.98 \\
$\begin{array}{l}\left.\text { Activated by zinc chloride ( } \mathrm{ZnCl}_{2}\right) \\
\text { (penetration coefficient - 0.4) with } \\
\text { subsequent activation of the carbon dioxide } \\
\left(\mathrm{CO}_{2}\right) \text { stream at the temperature 500 }{ }^{\circ} \mathrm{C}\end{array}$ & 0.61 & 0.17 & 0.088 & 15.7 \\
\hline
\end{tabular}

Activated carbons on the base of apricot kernel shells tested in aqueous solution at the dechlorination processes of JSC "VIZIT", in the test laboratory of JSC "KHIMFARM". The obtained activated carbons were checked in accordance with the required standards and investigated the physical chemical properties in the Accredited Test Center "SAPA" of M. Auezov' South Kazakhstan State University.

\section{Conclusion}

It was developed the high-performance, compact and reliable in operation device. It is suitable for the mechanical activation in the production of the powders of fine-dispersion and high activity. Based on the study of the process of mechanical activation of apricot kernel shells have been identified the feasibility of destruction method at high loading speeds. The study has shown that the shells activation in the double chamber of the mechanical activator at the presence of water leads to a multiple increase in the porosity and the formation of fresh surface.

It was identified the influence of thermal and chemical activations for the structural characteristics of the surfaces. Activated carbons for the development of porous structure have formed the following series: processed $\mathrm{ZnCl}_{2}$ and $\mathrm{CO}_{2}>$ processed $\mathrm{ZnCl}_{2}>$ processed $\mathrm{H}_{2} \mathrm{SO}_{4}>$ processed $\mathrm{H}_{3} \mathrm{PO}_{4}$. For samples treated by acid the activation mode optimal parameters are: concentration $-30 \%$; time -2 hours. For samples treated by $\mathrm{ZnCl}_{2}$, the 
optimal parameters of activation modes are: penetration ratio -0.4 ; time -3 hours (total pore volume $9.8 \cdot 10^{-4}$ $\mathrm{m}^{3} / \mathrm{kg}$ ). For samples treated by $\mathrm{ZnCl}_{2}$ with subsequent activation of $\mathrm{CO}_{2}$ optimal parameters are: temperature of $\mathrm{CO}_{2}-500{ }^{\circ} \mathrm{C}$, the penetration coefficient is 0.4 (total pore volume $11.4 \cdot 10^{-4} \mathrm{~m}^{3} / \mathrm{kg}$ ).

All above described studies have scientific and practical values. The identified specificities of the apricot stones porous structures permit to fit the optimal conditions for the obtaining of activated carbons by mechanical, chemical and thermal treatments. The findings indicate that the obtained samples of activated carbon by their physical-chemical and adsorption structural characteristics correspond to the known industrial analogues.

For further intentions, authors will consider an application of the developed activated carbon in the purification underground water and sewage. For this implementation will be calculated a mathematical model of the membrane apparatus with specific properties. In addition it will be studied colloid membrane behavior in the heterophase system.

\section{References}

Abechi, S. E., Gimba, C. E., Uziaru, A., \& Ndukwe, I. G. (2006). Comparative studies on adsorption of methylene blue (MB) by sawdust and walnut shells carbon coated with ZnO. Science World Journal, 1, 33-35.

Abu, B. M., Rakmi, A. R., Abdul, A. H. K., Siti, R. S. A., Zakiah, W. S., \& Safura, S. (2008). Removal of Adsorbable Organic Halides (AOX) from Recycled Pulp and Paper (P\&P) Mill Effluent Using Granular Activated Carbon-Sequencing Batch Biofilm. Reactor (GAC-SBBR). Modern Applied Science, 2(5), 37-45.

Ahmedna, M., Marshall, W. E., Husseiny, A. A., Goktepe, I., Ramu, M. R. (online: 2004). The use of nutshell carbons in drinking water filters for removal of chlorination by-products. J. Chem Technol Biotechnol, 79, 1092-1097. http://dx.doi.org/10.1002/jctb.1087

Alessandro, C., Martins, O. P., André, L., Cazetta, K. C., Bedin, D. A. S., Yamazaki, G. F. G., ... Vitor, C. A. (2015). Removal of tetracycline by $\mathrm{NaOH}$-activated carbon produced from macadamia nut shells: Kinetic and equilibrium studies. Chemical Engineering Journal, 260, 291-299. http://dx.doi.org/10.1016/j.cej.2014.09.017

Anas, N, M., \& Williamsm P. T. (2012). Pore characteristics of activated carbons from the phosphoric acid chemical activation of cotton stalks. Biomass and Bioenergy, 37, 142-149. http://dx.doi.org/10.1016/j.biombioe.2011.12.019

Angın, D., Altintig, E., \& Ennil, K. T. (2013). Influence of process parameters on the surface and chemical properties of activated carbon obtained from biochar. Chemical Activation Bioresource Technology, 148, 542-549. http://dx.doi.org/10.1016/j.biortech.2013.08.164

Anurov, S. A., Anurova, T. V., Klushin, V. N., Mukhin, V. M., \& Myshkin, V. E. (2011). Obtaining of carbonic adsorbents from vegetable waste products. 1- carbonization raw materials. Investigated in Russia, 14, 199-211.

Avramenko, V. A., Chernykh, V. V., Zemkova, L. A., Pershko, A. A., \& Sokolnitskaya, T. A. (1992). The method of obtaining activated carbon. Patent of USSR №1770273 A1.

Aygün, A., Yenisoy, K. S., \& Duman, I. (2003). Production of granular activated carbon from fruit stones and nutshells and evaluation of their physical, chemical and adsorption properties. Microporous and Mesoporous Materials, 66(2-3), 189-195. http://dx.doi.org/10.1016/j.micromeso.2003.08.028

Bhatnagar, A., Hogland, W., Marques, M., \& Sillanpää, M. (2013). An overview of the modification methods of activated carbon for its water treatment applications. Chemical Engineering Journal, 219, 499-511. http://dx.doi.org/10.1016/j.cej.2012.12.038

Branton, P., \& Bradley, R. H. (2011). Effects of active carbon pore size distributions on adsorption of toxic organic compounds. Adsorption, 17, 293-301. http://dx.doi.org/10.1007/s10450-010-9284-4

Dilek, A., Esra, A., \& Tijen, E. K. (2013). Influence of process parameters on the surface and chemical properties of activated carbon obtained from biochar by chemical activation. Bioresource Technology, 148, 542-549. http://dx.doi.org/10.1016/j.biortech.2013.08.164

Erdoğan, S., Önal, Y., Akmil, B. C., Bilmez, E. S., Sarıcı, Ö. Ç., Köseoğlu, E., \& İçduygu, G. (2005). Optimization of nickel adsorption from aqueous solution by using activated carbon prepared from waste apricot by chemical activation. Applied Surface Science, 252(5), 1324-1331. http://dx.doi.org/10.1016/j.apsusc.2005.02.089 
Golubev, V. P., Mukhin, V. M., Tamamyan, A. N., Zubova, N. D., \& Maximov, Yu. N. (1998). The method of obtaining activated carbon from fruit stones and nutshell. Patent of Russian Federation № 2111923 C1.

Gregg, S. J., \& Sing, K. S. (1982). Adsorption, Surface Area and Porosity. London, p.303

Heinike, G. (1984). Tribochemistry. Akademie-Verlag, Berlin, p.341.

Ioannidou, O., \& Zabaniotou, A. (2007). Agricultural residues as precursors for activated carbon production. Renewable and Sustainable Energy Reviews, 11(9), 1966-2005. http://dx.doi.org/10.1016/j.rser.2006.03.013

Janusz, W., Khalameida, S., Sydorchuk, V., Skwarek, E., Zazhigalov, V., Skubiszewska, Zi J., \& Leboda, R. (2010). Some properties of milled vanadium phosphates. Adsorption, 16, $333-341$. http://dx.doi.org/10.1007/s10450-010-9238-x

Karima, B., AbdelKrim, S., \& Mohamed, H. (2013). Synthesis of activated carbon based on apricot stones for wastewater treatment. Desalination and Water Treatment, 52(7-9), 1422-1433.

Kazemipour, M., Ansari, M., Sh.Tajrobehkar, Majdzadeh, M., \& Reihani, K. H. (2008), Removal of lead, cadmium, zinc, and copper from industrial wastewater by carbon developed from walnut, hazelnut, almond, pistachio shell, and apricot stone. Journal of Hazardous Materials, 150(2), 322-327. http://dx.doi.org/10.1007/s10450-010-9238-x

Keltsev, N. V. (1984). Bases of adsorption technology. Moscow, Chemistry, p.592

Khan, A. (1985). Activated carbons from greek nutshell. Res. and Ind., 1, 13-16.

Kolyshkin, D. A., \& Mikhaylova, K. K. (1972). Activated carbons. Moscow, Chemistry p.58

Kutics, K, Kotsis, L., Szolesfnyi, P., \& Argyelan, J. (1984). Production of activated carbon from walnut shell I. Adsorption investigations and study of application characteristics. Hung. J. Ind. Chem. 12, 3, 319-327.

Linares-Solano, A., \& Rodpez-Gonzales, J. de D. (1984). The two-stag air-CO2 activation in the preparation of activated carbons. Adsorpt.Sci.andTehnol 1, 3, $233-234$.

Lopez-Carzon, E. J., Moreno-Castilla, G., Guerrero-Ruis, A., Rodrigues-Reinoso, F., \& Lopez-Gonzalez, J. (1984). High temperature adsorption of hydrocarbons by activated carbons prepared from olive stones. Adsorpt. Sci. and Tehnol. 1, 1, 103-109.

Lutsik, V. I., Sobolev, A. V., Yu., V., \& Chursanov, A. V. (2008). Physical-chemical methods analysis. Educated textbook, Tver, p.208

Martínez de Yuso, A., Rubio, B., \& Teresa, I. M. (2014). Influence of activation atmosphere used in the chemical activation of almond shell on the characteristics and adsorption performance of activated carbons. Fuel Processing Technology, 119, 74-80. http://dx.doi.org/10.1016/j.fuproc.2013.10.024

Martinez, M. L., Moiraghi, L., Agnese, M., \& Guzman, C. (2003). Making and some properties of activated carbon produced from agricultural industrial residues from Argentina. J. Arg. Chem. Soc., 91(4-6), 103-108.

Martínez, M. L., Torres, M. M., Guzmán, C. A., \& Maestri, D. M. (2006). Preparation and characteristics of activated carbon from olive stones and walnut shells. Industrial Crops and Products, 23(1), 23-28. http://dx.doi.org/10.1016/j.indcrop.2005.03.001

Melchenko, G. G., \& Yunnikova, N. V. (2005). Analytical chemistry and physical-chemical methods analysis. Quantitative chemical analysis. Kemerovo Technological Food Industry Institute, Kemerovo, p.105

Nunell, G. V., Fernandez, M. E., Bonelli, P. R., \& Cukierman, A. L. (2015). Nitrate uptake improvement by modified activated carbons developed from two species of pine cones. Journal of Colloid and Interface Science, 440, 102-108. http://dx.doi.org/10.1016/j.jcis.2014.10.058

Okman, I., Karagöz, S., Tay, T., \& Erdem, M. (2014). Activated Carbons From Grape Seeds By Chemical Activation With Potassium Carbonate And Potassium Hydroxide. Applied Surface Science, 293, $138-142$. http://dx.doi.org/10.1016/j.apsusc.2013.12.117

Park, Y., Lee, J. H., Kim, Y. J., \& Kim, H. H. (2006). The Preparation of New Adsorbent by Walnut Shells. Applied Chemistry 10, 2, 645-648.

Piotr, N., Justyna, K., \& Robert, P. (2015). Comparison of physicochemical and sorption properties of activated carbons prepared by physical and chemical activation of cherry stones. Powder Technology, 269, 312-319. http://dx.doi.org/10.1016/j.powtec.2014.09.023

Rodrigues-Reinoso, F. D., Lopez-Gonzales, J. de, \& Berenguerm, C. (1984). Activated carbons from almond 
shells II. Caracterization of the pore structure. Carbon 22, 1, 13-18. http://dx.doi.org/10.1016/0008-6223(84)90128-3

Rodriguez-Reinoso, F., Martin-Martinez, J. M., Molino-Sabio, Perez-Lleodo, \& Prado-Burguete, C. A. (1985). Comparison of the porous texture of two CO2 activated botanic materials. Carbon 23, 1, 19-24. http://dx.doi.org/10.1016/0008-6223(85)90191-5

Sataeyv, M. I., Mamitova, A. D., Shakirov, B. S., Sataeva, L. M., Turisbaeva, A. K., \& Smagul, A. T. (2001). The method of activated carbon. Patent of Kazakhstan № 10536

Satayev, M., Shakirov, B., Mutaliyeva, B., Satayeva, L., Altynbekov, R., Baiysbay, O., \& Alibekov R. (2012). Mathematical modeling of methoxyanabasine $\mathrm{C} 11 \mathrm{H} 16 \mathrm{~N} 2 \mathrm{O}$ polymer solution ultrafiltration. Heat Mass Transfer, 48(6), 979-987. http://dx.doi.org/10.1007/s00231-011-0948-8

Sato, E. (1986). Activated carbon. USA Patent № 4616001.

Şentorun, S. Ç., Uçak-Astarlıo`lu, M. G., Artok L., \& Sarıcı Ç. (2006). Preparation and characterization of activated carbons by one-step steam pyrolysis/activation from apricot stones. Microporous and Mesoporous Materials, 88(1-3), 126-134. http://dx.doi.org/10.1016/j.micromeso.2005.09.003

Skubiszewska-Zieba, J., Sydorchuk, V. V., Gun'ko, V. M., \& Leboda, R. (2011). Hydrothermal modification of carbon adsorbents. Adsorption, 10, 919-927. http://dx.doi.org/10.1007/s10450-011-9369-8

Soleimani, M., \& Kaghazchi, T. (2008). Adsorption of gold ions from industrial wastewater using activated carbon derived from hard shell of apricot stones - An agricultural waste. Bioresource Technology, 99(13), 5374-5383. http://dx.doi.org/10.1016/j.biortech.2007.11.021

Strelko, V. V., Kartel, N. T., Puziy, A. M., Chikhman, Yu. P., \& Titarenko, V. N. (1996). Carbonic sorbent and method of its obtaining. Patent of Russian Federation №2064429

Suresh, K., Reddy, K., Shoaib, A. A., \& Srinivasakannan, C. (2012). A comparison of microstructure and adsorption characteristics of activated carbons by $\mathrm{CO} 2$ and $\mathrm{H} 3 \mathrm{PO} 4$ activation from date palm pits. New Carbon Materials, 27(5), 344-351. http://dx.doi.org/10.1016/S1872-5805(12)60020-1

Syafalni, S., Ismail, A., Aderiza, B., Siti Nor Farhana, Z., \& Rohana, A. (2013). Peat Water Treatment Using Combination of Cationic Surfactant Modified Zeolite, Granular Activated Carbon, and Limestone. Modern Applied Science, 7(2), 39-49. http://dx.doi.org/10.5539/mas.v7n2p39

Tangjuank, S., Insuk, N., Tontrakoon, J., \& Udeye ,V. (2009). Adsorption of Lead (II) and Cadmium (II) ions from aqueous solutions by adsorption on activated carbon prepared from cashew nut shells. World Academy of Science. Engineering and Technology, 52, 110-116.

Tlas, M., Olontsev, V. F., Glushakov, S. L., Limonov, N. V., Mamonov, O. V., Salekh, M., Kuntsev, A. D., \& Polyakov, N. S. (1998). The method of obtaining activated carbon. Patent of Russian Federation № 2104925.

Torosyan, V. F. (2010). Analytical chemistry and physical-chemical methods analysis. Practical guidelines: educated-methodical textbook, Tomsk: Tomsk Polytechnics University Edition

Youssef, A. M., Radwan, N. R. E., Abdel-Gawad, I., \& Singer, G. A. A. (2005). Textural properties of activated carbons from apricot stones. Colloids and Surfaces A: Physicochemical and Engineering Aspects, 252(2-3), 143-151. http://dx.doi.org/10.1016/j.colsurfa.2004.09.008

Zabihi, M., Haghighi, Asl A., \& Ahmadpour, A. (2010). Studies on adsorption of mercury from aqueous solution on activated carbons prepared from walnut shell. Journal of Hazardous Materials, 174, 251-256. http://dx.doi.org/10.1016/j.jhazmat.2009.09.044

\section{Copyrights}

Copyright for this article is retained by the author(s), with first publication rights granted to the journal.

This is an open-access article distributed under the terms and conditions of the Creative Commons Attribution license (http://creativecommons.org/licenses/by/3.0/). 